\title{
PERUBAHAN BEBERAPA SIFAT FISIS DAN KIMIA PASTA GAMBIR SELAMA PENYIMPANAN
}

\author{
Anwar Kasim, Yoli Sub'han dan Netty Sri Indeswari \\ Fakultas Pertanian Universitas Andalas Padang
}

\begin{abstract}
Studying about the change of physical and chemical properties Gambir paste during 28 days was conducted in order to know the change primarily the chemical content and physical properties as storage consequences. Experimental design was used completely randomized design for 4, 8, 12, 16, 20, 24, and 28 days storage periods. Replication was two and as a control was used paste non treatment. F-test and T-Dunnet test were applicated for statistical analysis. The result indicated that treatment can not change physical properties but change the chemical properties gambir paste. The initial water contents of gambir paste was $72.26 \%$ and after 28 days storage $71.68 \%$. Color of gambir paste was still yellow during storage. The initial non water soluble substance was $6.96 \%$ and after 28 days storage $4.69 \%$. The initial non alcohol soluble substance was $14.83 \%$ and after 28 days storage $13.15 \%$. The initial chatechin contents was $72.22 \%$ and after 28 days storage $65.38 \%$. The initial tannin contents $38.68 \%$ and after 28 days storage $35.12 \%$. Total ash content of gambir paste was $2.72 \%$.
\end{abstract}

Keywords : gambir, paste, storage, change, properties.

\section{PENDAHULUAN}

Gambir adalah salah satu komoditas hasil pertanian yang dapat digunakan sebagai bahan baku dalam industri farmasi, kosmetik, cat, penyamakan kulit dan digunakan juga sebagai campuran bahan pelengkap makan sirih ${ }^{[1]}$.

Dari hasil survey pendahuluan yang dilakukan pada salah satu sentra pengolahan gambir Sumatera Barat, yaitu Pesisir Selatan, proses pencetakan dari pasta gambir dan pengeringannya berlangsung sekitar 15-30 hari. Pada musim hujan akan semakin lama lagi sebab pengeringan dengan sinar matahari sulit dilakukan. Biasanya, bila tidak bisa dijemur dengan sinar matahari, pasta gambir tersebut dicetak dan dikeringkan di atas tungku perebusan.

Harga gambir sering tidak stabil di pasaran, akibatnya petani banyak tidak mengolah gambir kalau harganya murah dan sebaliknya petani akan mengolah gambir kalau harganya mulai meningkat. Penumpukan pasta gambir bisa terjadi saat harga gambir naik karena produksi pasta gambir dari petani meningkat, sedangkan pencetakan dan pengeringannya tidak dapat berlangsung cepat. Hasil survey pada daerah produksi Kabupaten Lima Puluh Kota, ketika harga gambir mahal pedagang ada kalanya membeli gambir dalam bentuk pasta, lalu mencetak dan mengeringkannya sendiri. Jadi telah terjadi perubahan bentuk pemasaran gambir dari biasanya, dimana telah ada permintaan terhadap pasta gambir oleh pedagang ${ }^{[2]}$.

Pada pedagang perantara ditemukan adanya usaha untuk menghilangkan atau mengurangi kotoran-kotoran atau bahan-bahan asing yang menyebabkan turunnya mutu gambir. Proses itu dilakukan dengan cara memberikan perlakuan tertentu terhadap pasta gambir ataupun gambir kering. Salah satu cara yang dilakukan adalah gambir dicuci dengan air panas dan air dingin ${ }^{[3,4]}$. Dengan begitu berarti pasta gambir tidak mutlak dikeringkan.

Hanya saja kandungan air yang masih tinggi dan banyaknya komponen kimia yang ada pada pasta gambir memungkinkan terjadinya berbagai macam reaksi di dalamnya apabila dilakukan penyimpanan. Reaksi yang akan 
terjadi mungkin akan menaikkan atau menurunkan jumlah salah satu komponen pasta gambir, merubah ikatan kimia dan memodifikasi bentuknya. Sehubungan dengan hal itu, dilakukan penelitian untuk mengetahui sejauh mana perubahan yang terjadi selama penyimpanan pasta gambir selama 28 hari.

\section{METODOLOGI}

\section{Alat dan Bahan}

Peralatan yang digunakan adalah timbangan analitis, termometer, labu ukur $500 \mathrm{~mL}$, alat titrasi, pengaduk, spektrofotometer, plastik dan tabung plastik, gelas ukur, gelas piala, krusgooch, asbes, pemanas air, desikator, pompa vakum dan cawan porselen.

Bahan yang digunakan dalam penelitian ini adalah pasta gambir yang diperoleh dari Burung-burung Balantai, Tarusan Pesisir selatan, akuades, alkohol, chatechin standar, etil asetat, ferrous tartat, buffer fosfat $(\mathrm{pH} 7,5)$ dan etil galat.

\section{Prosedur}

Pasta gambir yang digunakan sejumlah $16 \mathrm{~kg}$ dan diaduk rata dan kemudian ditimbang masing-masing $1 \mathrm{~kg}$ dan dimasukkan ke dalam kemasan plastik yang dapat ditutup rapat. Sampel tersebut disimpan sesuai dengan lama perlakuan penyimpanan. Kondisi ruang penyimpanan adalah ruang biasa dimana tidak ada modifikasi suhu dan udara penyimpanan.

Penelitian dilakukan dengan menggunakan Rancangan Acak Lengkap (RAL) dengan 8 perlakuan lama penyimpanan dan 2 ulangan setiap perlakuan. Kemudian dilanjutkan uji perbandingan T-Dunnet pada taraf nyata 5\%.

Pengamatan yang dilakukan terhadap sifat fisis, meliputi kadar air, warna pasta gambir yang pastanya disimpan dengan sifat kimia meliputi kadar bahan yang tidak larut dalam air dan dalam alkohol, kadar chatechin, kadar tanin, kadar abu, dan bentuk spektrum ultraviolet larutan gambir ${ }^{[5,6]}$.

\section{HASIL DAN PEMBAHASAN}

\section{Kadar Air Pasta Gambir}

Hasil analisis sidik ragam terhadap kadar air pasta gambir selama penyimpanan menunjukkan perbedaan yang tidak nyata pada uji taraf 5\%, sehingga uji larut dengan analisis T-Dunnet tidak dilakukan. Berikut ditampilkan pada Tabel 1 rata-rata kadar air pasta gambir yang disimpan sesuai perlakuan lama penyimpanan. Jadi dapat disimpulkan bahwa terjadi perubahan kadar air pasta gambir yang disimpan selama 28 hari.

\section{Perubahan Warna Pasta Gambir dan Gambir Keringnya}

Warna pasta gambir selama penyimpanan tidak mengalami perubahan yaitu tetap kuning tapi bila pasta yang telah mengalami penyimpanan tersebut dikeringkan maka warna gambir keringnya yang berupa bubuk berubah mulai dari warna kuning, coklat sampai coklat kehitam-hitaman. Jadi warna gambir kering tersebut menjadi lebih gelap dengan makin lamanya penyimpanan pasta gambir.

Terlihat bahwa warna pasta gambir tidak berubah walaupun telah disimpan 28 hari namun warna gambir keringnya memperlihatkan perbedaan warna akibat penyimpanan, dimana makin lama penyimpanan pasta mengakibatkan warna gambir keringnya cenderung berubah menjadi gelap. Perubahan ini diperkirakan akibat berlangsungnya reaksi oksidasi selama penyimpanan pasta.

Tabel 1. Rata-rata Kadar Air Pasta Gambir pada Berbagai Penyimpanan

\begin{tabular}{cc}
\hline $\begin{array}{c}\text { Lama Penyimpanan } \\
\text { Pasta Gambir (hari) }\end{array}$ & Kadar Air (b/b)\% \\
\hline 0 & 73,26 \\
4 & 72,23 \\
8 & 72,47 \\
12 & 72,30 \\
16 & 72,65 \\
20 & 73,57 \\
24 & 72,78 \\
28 & 71,68 \\
\hline
\end{tabular}




\section{Bahan Tidak Larut Air dan Alkohol dari Gambir}

Analisis sidik ragam terhadap bahan tidak larut dalam air dan alkohol menunjukkan bahwa penyimpanan pasta gambir selama 28 hari tidak memberikan pengaruh yang nyata terhadap kadar bahan tidak larut air dan alkohol. Pada Tabel 3 ditampilkan kadar-kadar bahan tersebut.

\section{Kadar Chatechin dan Tanin}

Kadar chatechin dari gambir yang pastanya disimpan nilainya bervariasi menurut perlakuan lama penyimpanan. Kadar chatechin dari gambir yang pastanya tidak disimpan $72,22 \%$ dan kadar chatechin dari gambir yang pastanya disimpan selama 28 hari $65,39 \%$. Analisis sidik ragam terhadap kadar chatechin memperlihatkan yang nyata, namun setelah diuji dengan T-Dunnet ternyata tidak berbeda nyata antara kadar chatechin gambir akibat perlakuan penyimpanan. Angka-angka yang terletak pada jalur yang sama diikuti oleh huruf kecil yang sama tidak berbeda menurut uji $\mathrm{T}$ pada taraf $5 \%$.
Kadar tanin dari gambir yang pastanya tidak disimpan 38,68\% sedangkan kadar tanin dari gambir yang pastanya disimpan selama 28 hari $35,12 \%$. Penyimpanan pasta mulai dari 4 hari sampai 28 hari memiliki kadar tanin gambir yang jauh lebih rendah dari pasta gambir yang tidak disimpan. Walaupun terjadi kenaikan kadar tanin dalam selang penyimpanan pasta gambir 4 hari sampai 28 hari namun tidak begitu besar.

\section{Pengamatan Spektrum Ultra Violet (UV) Gambir}

Pengamatan spektrum UV dari gambir yang pastanya mendapat penyimpanan, bertujuan untuk mengetahui apakah ada perubahan bentuk spektrum flavonoid gambir selama masa penyimpanan pasta. Pengamatan spektrum UV terhadap flavonoid gambir yang pastanya telah disimpan dilakukan dengan cara melarutkan gambir ke dalam pelarut etil asetat, kemudian dilakukan pengamatan dengan spektrofotometer. Spektrum dari gambir yang pastanya terlebih dahulu disimpan disajikan pada Gambar 1.

Tabel 2. Warna Pasta Gambir dan Warna Gambir Kering yang Pastanya Disimpan pada Berbagai Tingkat Lama Penyimpanan

\begin{tabular}{ccc}
\hline $\begin{array}{c}\text { Lama penyimpanan pada } \\
\text { pasta gambir (hari) }\end{array}$ & Warna pasta gambir & Warna gambir kering \\
\hline 0 & Kuning & Kuning \\
4 & Kuning & Kuning \\
8 & Kuning & Coklat \\
12 & Kuning & Coklat \\
16 & Kuning & Coklat kehitaman \\
20 & Kuning & Coklat kehitaman \\
24 & Kuning & Coklat kehitaman \\
28 & Kuning & Coklat kehitaman \\
\hline
\end{tabular}

Tabel 3. Kadar Bahan Tidak Larut Air dan Tidak Larut Alkohol dari Gambir Kering yang Pastanya Disimpan pada Berbagai Tingkat Lama Penyimpanan

\begin{tabular}{ccc}
\hline $\begin{array}{c}\text { Lama Penyimpanan pada } \\
\text { Pasta Gambir (hari) }\end{array}$ & Bahan tidak larut air (\%) & Bahan tidak larut alkohol \\
\hline 0 & 6,96 & 14,83 \\
4 & 5,63 & 14,98 \\
8 & 6,87 & 14,83 \\
12 & 6,78 & 17,70 \\
16 & 3,38 & 16,35 \\
20 & 5,93 & 13,67 \\
24 & 4,55 & 13,15 \\
28 & 4,69 & 13,15 \\
\hline
\end{tabular}


Dari hasil uji T pada taraf 5\% diketahui bahwa panjang gelombang untuk nilai absorban maksimum berbeda nyata antara gambir berbagai perlakuan. Panjang gelombang dimaksud berkisar antara 280,0 sampai 280,9. nilai absorban maksimum untuk tiap panjang gelombang maksimum yang dimiliki masingmasing gambir juga berbeda menurut uji $\mathrm{T}$ pada taraf 5\%. Nilai absorban berkisar antara 0,299 - 0,443. Nilai absorban maksimum chatechin standar 0,454 pada panjang gelombang 280,4.

\section{Kadar Abu Pasta Gambir}

Pengukuran kadar abu hanya dilakukan terhadap pasta gambir penyimpanan 0 hari didapatkan kadar abu sebesar 2,72\%. Bila mengacu kepada SNI 01-3391-1991 maka kadar abu tersebut masih di bawah nilai maksimal 5\%.

Tabel 4. Kadar Chatechin dan Tanin dari Gambir Kering yang Pastanya Disimpan pada Berbagai Tingkat Lama Penyimpanan

\begin{tabular}{ccc}
\hline $\begin{array}{c}\text { Lama penyimpanan pada } \\
\text { pasta gambir (hari) }\end{array}$ & $\begin{array}{c}\text { Kadar chatechin } \\
(\%)\end{array}$ & Kadar Tannin (\%) \\
\hline 0 & $72,22 \mathrm{a}$ & $38,68 \mathrm{a}$ \\
4 & $79,73 \mathrm{a}$ & $35,11 \mathrm{a}$ \\
8 & $80,64 \mathrm{a}$ & $34,28 \mathrm{a}$ \\
12 & $62,19 \mathrm{a}$ & $34,04 \mathrm{a}$ \\
16 & $51,71 \mathrm{a}$ & $33,46 \mathrm{a}$ \\
20 & $65,39 \mathrm{a}$ & $32,81 \mathrm{a}$ \\
24 & $34,19 \mathrm{a}$ & $34,19 \mathrm{a}$ \\
28 & $65,38 \mathrm{a}$ & $35,12 \mathrm{a}$ \\
\hline
\end{tabular}

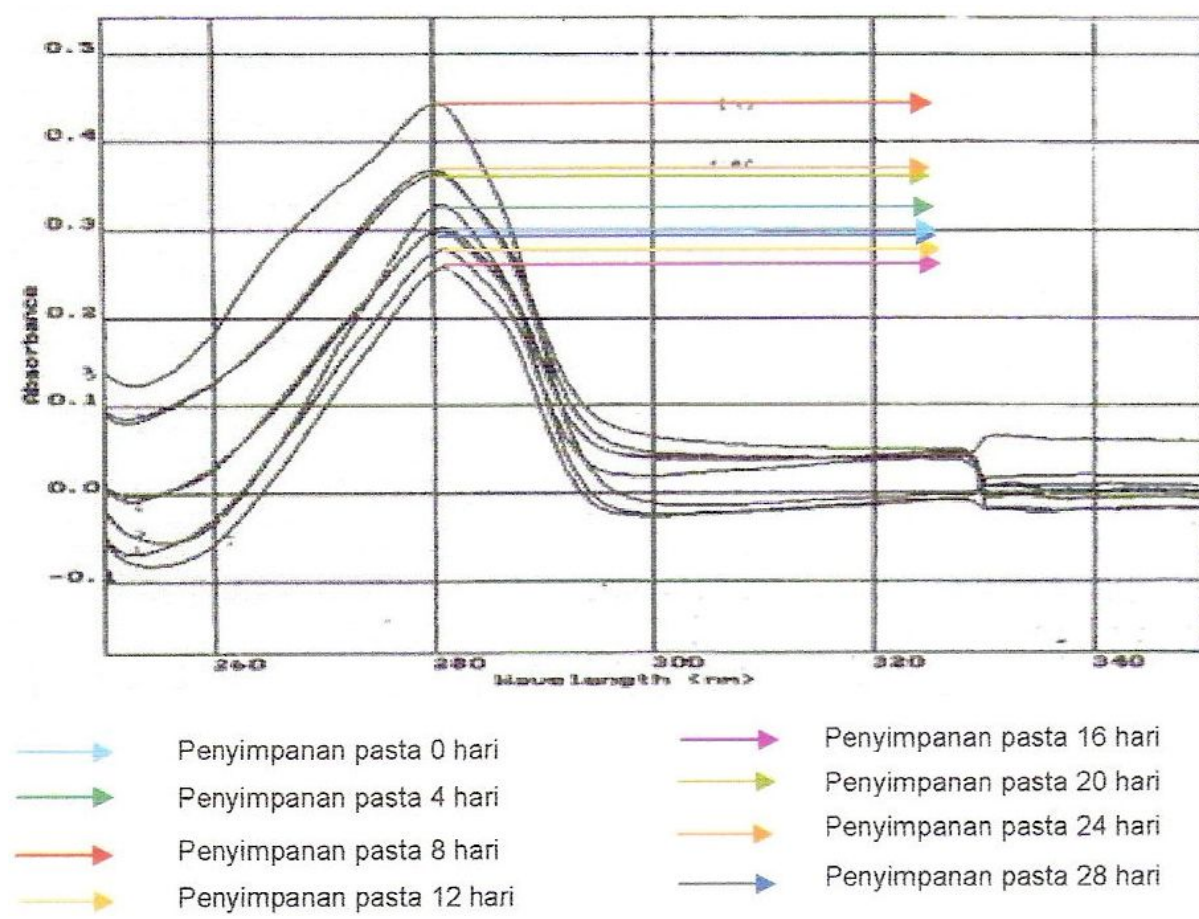

Gambar 1. Spektrum ultra violet gambir dari pasta gambir yang disimpan pada berbagai perlakuan lama penyimpanan. 


\section{KESIMPULAN}

Dari pelaksanaan penelitian dapat disimpulkan bahwa penyimpanan pasta gambir selama 28 hari tidak merubah sifat fisiknya tetapi merubah kadar kandungan kimia utamanya.

Kadar air pasta gambir sebelum disimpan $72,26 \%$ dan diakhir penyimpanan $71,26 \%$ namun tidak berbeda nyata setelah dianalisa statistik. Warna pasta gambir selama penyimpanan tidak berubah atau tetap berwarna kuning.

Kadar bahan tidak larut dalam air dan bahan tidak larut dalam alkohol dari gambir yang pastanya mendapat perlakuan perbedaan lama penyimpanan tidak mengalami perubahan yang nyata secara statistik. Kadar bahan tidak larut dalam air dari gambir yang pastanya tidak disimpan $6,96 \%$ sedangkan yang pastanya disimpan 28 hari 4,69\%. Bahan tidak larut alkohol dari gambir yang pastanya tidak disimpan $14,83 \%$ dan yang pastanya disimpan 28 hari $13,15 \%$.

Kadar chatechin dari gambir yang pastanya mendapat perlakuan penyimpanan cenderung meningkat, namun tidak berlangsung terus menerus selama penyimpanan tetapi cenderung naik terjadi diawal penyimpanan. Kadar chatechin tertinggi terdapat pada gambir yang pastanya disimpan selama 8 hari yaitu sebesar $80,64 \%$, sedangkan chatechin dari gambir yang pastanya tidak disimpan sebesar $72,22 \%$ dan pastanya disimpan paling lama (28 hari) $65,38 \%$.

Kadar tanin dari gambir yang pastanya disimpan menurun dibandingkan dengan kadar tanin gambir yang pastanya tidak disimpan. Dimana kadar tanin dari gambir yang pastanya disimpan 38,68\%. Walaupun terjadi perubahan kadar tanin selama penyimpanan tapi itu tidak terlalu besar dari kadar tanin yang pastanya tidak disimpan, kadar tanin diakhir penyimpanan sebesar $35,12 \%$.

Spektrum UV dari gambir yang pastanya mendapat perlakuan penyimpanan menunjukkan bahwa penyimpanan pasta tidak menyebabkan terjadinya perubahan spektrum. Sedikit perubahan terjadi pada nilai absorban maksimum panjang gelombang dengan nilai absorban maksimum. Kadar pasta abu pasta gambir penelitian $2,72 \%$.

\section{DAFTAR PUSTAKA}

1. Anonymous, Departemen Perdagangan Sumbar, 1993, Pedoman Peningkatan Mutu Gambir, Kanwil Departemen Perdagangan Sumatra Barat.

2. Nazir, N., 2000, Gambir, Budidaya, Pengolahan dan Prospek Diversifikasinya. Yayasan Hutanku Sumatra Barat.

3. Muchtar, H., Yusmeiarti, 2000, Teknologi Pemurnian Gambir sebagai Sumber Chatechin untuk Bahan Industri, Bulletin BPID Vol II(1).

4. Muctar, H., 2000, Teknologi Pemurnian Gambir, Makalah Pada Seminar Nasional. Hasil-Hasil Pertanian dan Pengkajian Pertanian. BBPT Sukarami dan Peragi. Padang.

5. Kasim, A., 2001, Analisis Karbohidrat dan Abu dari Gambir, Majalah STIGMA Volume IX No. 3, Fakultas Pertanian Universitas Andalas, Padang.

6. Markham, K. R., 1998, Cara Mengidentifikasi Flavonoid, Penerbit ITB Bandung. 